\title{
Pre-emptive Use of Riboflavin in a Rat Model of Bilateral Cavernous Nerve Injury
}

\section{Bilateral Kavernozal Sinir Hasarı Sıçan Modelinde Preemptif Riboflavin Tedavisinin Etkileri}

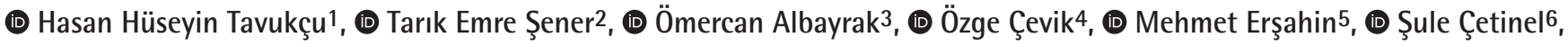 \\ (D) Nurdan Bülbül6, (1D Göksel Şener ${ }^{3}$ \\ 1 Istanbul Bilim University, İstanbul Florence Nightingale Hospital, Clinic of Urology, Istanbul, Turkiye \\ 2 Marmara University Faculty of Medicine, Department of Urology, Istanbul, Turkiye \\ 3 Marmara University Faculty of Pharmacy, Department of Pharmacology, İstanbul, Turkiye \\ ${ }^{4}$ Adnan Menderes University Faculty of Medicine, Department of Biochemistry, Aydın, Turkiye \\ 5istanbul Medeniyet University Faculty of Medicine, Department of Neurosurgery, istanbul, Turkiye \\ 6Marmara University Faculty of Medicine, Department of Histology and Embryology, İstanbul, Turkiye
}

\section{What's known on the subject? and What does the study add?}

Penile rehabilitation is an important approach for patients after nerve-sparing radical prostatectomy. Many treatment strategies are being applied aiming rapid healing for erectile function. Riboflavin has never been used for penile rehabilitation before. This study supports riboflavin use for penile rehabilitation, especially in preemptive approach.

\begin{abstract}
Objective: Erectile dysfunction is commonly encountered after radical prostatectomy due to cavernous nerve injury (CNI). We investigated the effects of riboflavin $(\mathrm{Rb})$ on bilateral $\mathrm{CNI}$ in a rat model.

Materials and Methods: Twenty-four male rats were divided into four groups: control (C), patients with bilateral CNI, those with CNI receiving postoperative $\mathrm{Rb}$ treatment $(\mathrm{CNI}+\mathrm{Rb})$, and those with $\mathrm{CNI}$ receiving pre- and post-operative $\mathrm{Rb}$ treatment $(\mathrm{Rb}+\mathrm{CNI}+\mathrm{Rb})$. Bilateral $\mathrm{CNI}$ was performed in all groups except for $\mathrm{C}$. The $\mathrm{CNI}+\mathrm{Rb}$ group was treated with $30 \mathrm{mg} / \mathrm{kg} \mathrm{Rb}$ daily after $\mathrm{CNI}$ for two weeks; the $\mathrm{Rb}+\mathrm{CNI}+\mathrm{Rb}$ group was treated with $30 \mathrm{mg} / \mathrm{kg} \mathrm{Rb}$ daily one week before CNI and then for two weeks after injury. Mean arterial pressure (MAP) and intracavernosal pressure (ICP) were measured 14 days after CNI in all groups. Tissue malondialdehyde, cyclic guanosine monophosphate, nerve growth factor, superoxide dismutase and total nitric oxide synthase (NOS) activities, neuronal NOS (nNOS) and inducible NOS (iNOS) were analyzed.

Results: ICP/MAP ratio was significantly lower in the CNI $(\mathrm{p}<0.01)$ and $\mathrm{CNI}+\mathrm{Rb}$ groups $(\mathrm{p}<0.05)$ compared to the control group, however, the $\mathrm{Rb}+\mathrm{CNI}+\mathrm{Rb}$ group had results comparable to the $\mathrm{C}$ group in terms of nNOS and iNOS expression in the Western Blot analysis.

Conclusion: $\mathrm{Rb}$ exerted anti-oxidative and anti-inflammatory effects on $\mathrm{CNI}$ in a $\mathrm{CNI}$ rat model. Rb can be a potential beneficial agent to improve erectile function in nerve-sparing radical prostatectomy patients as a preemptive penile rehabilitation strategy, although further clinical studies are needed.
\end{abstract}

Keywords: Cavernous nerve injury, Erectile dysfunction, Oxidative stress, Riboflavin

Öz

Amaç: Çalışmamızın amacı radikal prostatektomi modelinde erektil disfonksiyon tedavisinde riboflavinin (Rb) olası etkilerinin araştırılmasıdır. Gereç ve Yöntem: Yirmi dört erkek sıçan kontrol (K), bilateral kavernoz sinir hasarı (KSH), KSH+Rb ve Rb +KSH+Rb olmak üzere 4 gruba ayrıldı. Ön-tedavili KSH grubunda cerrahiden 1 hafta önce başlayarak toplam 3 hafta ve $\mathrm{KSH}+\mathrm{Rb}$ grubuna ise cerrahiden sonra 2 hafta süreyle 30 mg/kg dozunda Rb uygulandı. Deney sonunda intrakavernosal basınç (IKB) ve ortalama arteryel basınç (OAB) ölçümü yapıldı. Kavernoz doku örneklerinde malondialdehit (MDA), siklik guanozin monofosfat (c-GMP) ve sinir büyüme faktörü (NGF) düzeyleri ile süperoksid dismutaz (SOD) ve total nitrik oksit sentaz (NOS) aktiviteleri ölçüldü. Dokuların indüklenebilir NOS ve nöronal NOS protein ekspresyonları Western blot yöntemi ile tayin edildi.

Correspondence: Hasan Hüseyin Tavukçu MD, İstanbul Bilim University, İstanbul Florence Nightingale Hospital, Clinic of Urology, İstanbul, Turkiye Phone: +90 2123756565 E-mail: hhtavukcu@gmail.com ORCID-ID: orcid.org/0000-0003-0956-7460

Received: 17.01.2018 Accepted: 01.03.2018

Cite this article as: Tavukçu HH, Şener TE, Albayrak Ö, Çevik Ö, Erşahin M, Çetinel Ş, Bülbül N, Şener G. Pre-emptive Use of Riboflavin in a Rat Model of Bilateral Cavernous Nerve Injury. J Urol Surg 2018;5(2):98-104.

๑Copyright 2018 by the Association of Urological Surgery / Journal of Urological Surgery published by Galenos Publishing House. 


\section{Öz}

Bulgular: $\mathrm{KSH}, \mathrm{IKB} / \mathrm{OAB}$ değerlerinde anlamlı azalmaya $(\mathrm{p}<0.01)$ neden olurken preemptif Rb tedavili grupta bu değerler kontrol grubu değerlerine yaklaşmış olarak bulundu. KSH grubunda doku MDA düzeylerinin ve NOS aktivitesinin anlamlı olarak arttığı, c-GMP ve NGF düzeyleri ile SOD aktivitesinin anlamlı olarak azaldığı belirlendi. KSH sonrası uygulanan Rb tedavisi bu parametrelerdeki değişimleri geri çevirirken preemptif Rb tedavili gruplarda bu değerler kontrol gruba benzer düzeylere geldi.

Sonuç: Çalışmamızda Rb, hasarlı kavernoz dokuda antioksidan ve anti-enflamatuvar etki göstermiş ve böylece dokuyu koruyarak erektil fonksiyon kaybında iyileşme göstermiştir. Özellikle preemptif Rb kullanımının faydalı bir tedavi yaklaşımı sağlayabileceğini düşündürmekte olup insan çalışmalarıyla bu yaklaşım desteklenebilir.

Anahtar kelimeler: Kavernoz sinir hasarı, Erektil disfonksiyon, Oksidatif stres, Riboflavin

\section{Introduction}

More than one million men are diagnosed with prostate cancer worldwide, leading to more than 300.000 deaths each year (1). Many patients who had radical prostatectomy (RP) for prostate cancer experience side effects, one of which is the postoperative erectile dysfunction (ED) (2). Cavernous nerve injury (CNI) is the reason behind ED after RP (3). Even though different surgical techniques and modifications of RP have been studied to maintain erectile function (EF), the cavernous nerve (CN) is often injured by manipulations such as traction, compression or thermal damage. Regeneration of neural tissues after neural injury following RP is limited and happens over a very long period of time. Moreover, only a very small proportion of men who were preoperatively potent have spontaneous erections after RP (4).

Nitric oxide synthase (NOS), nitric oxide (NO), soluble guanylyl cyclase (sGC) and cyclic guanosine monophosphate (cGMP) have major roles in penile erection physiology. NO is synthesized in the $\mathrm{CN}$ via neuronal NOS (nNOS) (5). NO, which is a ubiquitous neurotransmitter, consists of L-arginine and is released by nerve terminals. It then spreads into the neighboring smooth muscle cells and induces $\mathrm{sGC}$, and this process increases the intracellular level of cGMP. Hence, the relaxation of smooth muscle in the corpus cavernosum as well as the penile arterioles is triggered by L-arginine. Meanwhile, phosphodiesterase type 5 inhibitors (PDE5i) prevent the catabolism of cGMP, which is the major supporting agent for penile erection (6). The pathophysiology behind $\mathrm{CNI}$ is not only nerve damage but also the accompanying oxidative stress (7), as the main cause of nerve damage is the increase in reactive oxygen species due to a decrease in NO. Superoxide radicals augment apoptosis, cause formation of peroxynitrite and can lead to dysfunction of the endothelium $(5,8,9)$. Peroxynitrite, which stimulates superoxide dismutase (SOD), produces ineffective relaxation of smooth muscle and can stimulate adhesion of platelets to endothelium. Thus, endothelial dysfunction and increased NO destruction result in corporal veno-occlusive dysfunction and impairment of $\operatorname{EF}(5,6)$.
The nerve-sparing RP technique, which aims to protect the CNs and thereby provide penile innervation via regulation of the vascular homeostasis of the penis, maintains EF effectively (10). Other techniques or approaches include nerve grafting (11), nerve reconstruction (12), pharmacological neuromodulation using immunophilins (13), neuroprotection using erythropoietin (14), electro-stimulation of the CN or pelvic ganglion (15), regulation of FK506-binding protein (16) and transferring of the herpes simplex virus vector (17). Studies seeking to preserve EF peri-operatively have examined tissue healing procedures such as muscle-derived cell injection (18), neuronal embryonic stem cell injection (19), intracavernous injection of adipose-derived stem cells (20), inhibition of neuronal inflammation or neuronal cell death using neurotrophic and growth factors $(21,22)$, and penile rehabilitation with PDE5i (4).

Riboflavin $(\mathrm{Rb})$ is water-soluble $\mathrm{B}$-complex vitamin that plays a role in various metabolic pathways and redox reactions via active coenzymes, flavin adenine dinucleotide and flavin mononucleotide (23). Rb protects tissues against neurotoxicity by alleviating oxidative stress, mitochondrial dysfunction, neurologic inflammation, glutamate and homocysteine toxicity (24).

The aim of this study was to investigate the essential role of Rb as an antioxidant and anti-inflammatory agent against ED in a bilateral $\mathrm{CNI}$ model in rats.

\section{Materials and Methods}

\section{Animals and Experimental Design}

Adult male Sprague-Dawley rats (250-300 g) were housed at a temperature-controlled room $\left(22 \pm 2{ }^{\circ} \mathrm{C}\right)$ with a 12 -hour lightdark cycle. Marmara University Animal Experiments Ethics Committee approved the study (number 78.2015.mar).

The rats were randomly divided into four groups with 6 rats in each: group 1, control (C) group, in which the rats underwent sham surgery and received carboxymethylcellulose (CMC) 0.5\% as vehicle/solvent for intraperitoneal dosing; group 2, in which the rats underwent surgery to induce $\mathrm{CNI}$ and received $\mathrm{CMC}$ 
$0.5 \%$ only; group $3, \mathrm{CNI}+\mathrm{Rb}$ group, in which the rats underwent surgery for $\mathrm{CNI}$ induction and received $\mathrm{Rb}(30 \mathrm{mg} / \mathrm{kg} / \mathrm{day}$ ip) for two weeks (25); and group 4, $\mathrm{Rb}+\mathrm{CNI}+\mathrm{Rb}$ group, in which the rats received $\mathrm{Rb}(30 \mathrm{mg} / \mathrm{kg} /$ day ip) before CNI induction then received $\mathrm{Rb}$ again (30 $\mathrm{mg} / \mathrm{kg} /$ day ip) following the surgery. For the $\mathrm{CNI}$ and $\mathrm{C}$ groups, in which the sham operation was performed, CMC solvent was applied for 15 days following the operation. In the pre-treatment CNI group, Rb was applied at a dose of $30 \mathrm{mg} / \mathrm{kg} /$ day ip for a total of three weeks starting one week before surgery and continuing for two weeks after the surgery in the $\mathrm{CNI}+\mathrm{Rb}$ group. $\mathrm{Rb}$ was dissolved in $0.5 \% \mathrm{CMC}$. $\mathrm{Rb}$ and $\mathrm{CMC}$ were purchased from Sigma Aldrich (St. Louis, MO, USA).

At the end of the experiment, under general anaesthesia, intracavernosal pressure (ICP) and mean arterial pressure (MAP) were measured and then cavernosal tissue samples were obtained for biochemical and histological analyses.

\section{Cavernous Nerve Stimulation and Intracavernosal Pressure/ Mean Arterial Pressure Measurement}

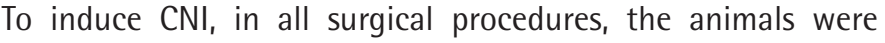
anaesthetized with ketamine $(100 \mathrm{mg} / \mathrm{kg}$ ) and xylazine $(6-9 \mathrm{mg} /$ $\mathrm{kg}$ ). After the animals were anaesthetized, following the shaving of the abdominal wall, a lower midline incision was made. The major pelvic ganglion and the $\mathrm{CN}$, a distinct structure arising from the ganglion and running caudally along the prostate in a groove between the urethra and rectum, were detected as previously described (26). A vascular bulldog clamp was applied to each $\mathrm{CN}, 5 \mathrm{~mm}$ distal to the ganglion. It was applied for 30 seconds, removed for 30 seconds, and then reapplied for an additional 30 seconds. Two weeks after the induction of $\mathrm{CNI}$ and sham operation, all animals were anaesthetized as described previously, and they underwent an operation during which electro-physiological erection assessment was conducted. With a transverse neck incision, subcutaneous layers and the underlying muscles were separated. Dissection and subsequent cannulation of the left internal carotid artery with a heparinized polyethylene-50 tube, connected to a pressure transducer and an amplifier unit (COMMAT Pharmacology \& Physiology Instruments, Ankara, Turkey) were performed. The amplifier which was connected to a module for data acquisition (MP 35 data acquisition system, Ankara, Turkey) allowed the MAP to be recorded using Biopac Student Lab PRO recording software (Biopac Systems Inc., Goleta, CA, USA). At the junction of the penis and pubic arch, dissection of the ischiocavernous muscle was performed and the penile tunica albuginea was visualized. ICP measurement was performed with a 24-gauge needle placed into the left penile crus which was connected to a transducer by a heparinized polyethylene- 50 tube. The laparotomy incision was extended below until the penile root. The $\mathrm{CN}$ was located bilaterally which is situated on both sides of the prostatic tissue. Following $\mathrm{CN}$ dissection with a micromanipulator, a stainless steel bipolar electrode with 1 $\mathrm{mm}$-apart parallel hooks was placed distally to the major pelvic ganglion. The electrode cable was connected to a STPTO2-A stimulator (COMMAT Pharmacology \& Physiology Instruments, Ankara, Turkey). The stimulation parameters were $1.5 \mathrm{~mA}, 20$ $\mathrm{Hz}$, pulse width 5 milliseconds, 35 milliseconds delays and 7.5 volts for 60 seconds each. Stimulation of the $\mathrm{CN}$ was performed and the data were individually recorded. The maximum ICP/MAP ratio was calculated and reported as percentage $(26,27)$.

\section{Biochemical Analysis}

\section{Measurement of Tissue Malondialdehyde Levels}

Corpus cavernosal tissue samples were homogenized with icecold potassium chloride $(150 \mathrm{mM})$ to determine MDA levels which shows the level of lipid peroxidation by monitoring thiobarbituric acid reactive substance formation as previously described. The results were expressed as $\mathrm{mmol} \mathrm{MDA} / \mathrm{mg}$ protein (24).

\section{Measurement of Superoxide Dismutase Activity}

SOD activity was measured according to the method described by Tavukcu et al. (28). A standard curve was prepared with bovine SOD (3000 U; S-2515; Sigma, St. Louis, MO, USA) as a reference. Absorbance readings were taken at 0 and 8 minutes of illumination, and the net absorbance was calculated (27).

\section{Measurement of Cyclic Guanosine Monophosphate Levels}

Amounts of cGMP in frozen tissue were determined in duplicate using an ELISA kit, according to the manufacturer's instructions (Enzo Life Sciences, Farmingdale NY, USA). A total protein assay was performed using the Bradford method. cGMP values were given as $\mathrm{pmol} / \mathrm{mg}$ protein (27).

\section{Measurement of Nerve Growth Factor Levels}

Measurement of nerve growth factor (NGF) was detected by sandwich-ELISA according to the manufacturer's instructions (Chemicon International Inc., Temecula, CA, USA). A total protein assay was performed using the Bradford method (29). NGF values were given as $\mathrm{pg} / \mathrm{mg}$ protein (27).

\section{Measurement of Tissue Nitric Oxide Synthase Activities}

Tissue samples were homogenised with phosphate-buffered saline (PBS) (pH 7.4) and centrifuged at $10.000 \times \mathrm{g}$ at $40{ }^{\circ} \mathrm{C}$. Supernatant was used for the NOS activity assay to determine the levels of NOS activity (EnzyChrom, BioAssay Systems, Hayward, CA, USA), following the manufacturer's protocol. According to the assay, one unit of NOS catalyzes the production of $1 \mu$ mole of NO per minute under the assay conditions ( $\mathrm{pH} 7.5$ and $\left.37^{\circ} \mathrm{C}\right)$. NOS activity was given as $\mathrm{U} / \mathrm{mg}$ protein (27). 


\section{Western Blot Analysis for Inducible Nitric Oxide Synthase and Neuronal Nitric Oxide Synthase}

Western blot analysis and measurement was performed for inducible NO synthase (iNOS) and nNOS release as previously described (30). The Bradford assay was used to detect protein concentrations in homogenized samples (29). Afterwards, 25 $\mu \mathrm{g}$ of protein was resolved in $12 \%$ sodium dodecyl sulfatepolyacrylamide gel electrophoresis and was transferred to nitrocellulose membrane (sc-3718, Santa Cruz Biotechnology) which was blocked with 5\% non-fat skim milk powder (Sigma, 70166) in Tris-buffered saline (TBS) and which was washed twice in (TBS+tween) TBST (TBS containing 0.1\% Tween-20) and incubated overnight with primary antibody (1:500 monoclonal rat anti-iNOS, sc-651 anti-nNOS, sc-648, anti-b-actin, sc-47778, Santa Cruz Biotechnology). The membrane was incubated with horseradish peroxidase (HRP)-conjugated secondary antibody (1:1000 goat anti-mouse IgG1-HRP, sc-2060 and goat antirabbit IgG-HRP sc-2004, Santa Cruz Biotechnology) for 2 hours. Chemiluminescence reagents (sc-2048, Santa Cruz Biotechnology using a Chemiluminescent Imaging System, Syngene, USA) were used to detect the blot. Data were analyzed using the ImageJ OD analysis software. Signals were normalized with respect to $\beta$-actin.

\section{Statistical Analysis}

GraphPad Prism 5.0 (GraphPad Software, San Diego; CA; USA) was used for the statistical analyses. All data were expressed as means \pm standard error of mean (SEM) Data groups were compared using an analysis of variance followed by Tukey's multiple comparison tests. A two-tailed $p$ value of less than 0.05 was considered statistically significant.

\section{Results}

ICP/MAP ratio was significantly lower in the $\mathrm{CNI}(\mathrm{p}<0.01)$ and $\mathrm{CNI}+\mathrm{Rb}$ groups $(\mathrm{p}<0.05)$ compared to that in the $\mathrm{C}$ group, however, the $\mathrm{Rb}+\mathrm{CNI}+\mathrm{Rb}$ treated group showed similar results

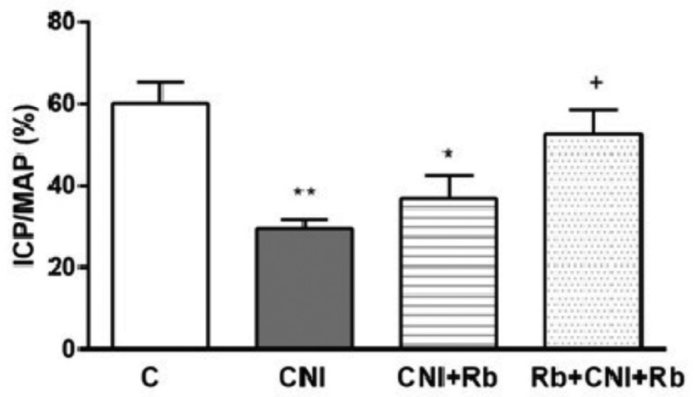

Figure 1. Intracavernosal pressure/mean arterial pressure results of all groups C: Control, CNI: Cavernosal nerve injury, Rb: Riboflavin. ${ }^{*} p<0.05,{ }^{* *} p<0.01$ : compared to group $C_{1}{ }^{+} p<0.05$ : compared to $\mathrm{CNI}$ to the $\mathrm{C}$ group (Figure 1).

MDA levels were significantly higher $(p<0.01)$ in the $\mathrm{CNI}$ group, while treatment with Rb significantly reduced the MDA levels in the $\mathrm{CNI}+\mathrm{Rb}$ and $\mathrm{Rb}+\mathrm{CNI}+\mathrm{Rb}$ groups, which achieved similar levels to that in the $\mathrm{C}$ group (Figure 2a).

SOD activity was significantly lower $(p<0.05)$ in the CNI group when compared with the $\mathrm{C}$ group, while the $\mathrm{Rb}+\mathrm{CNI}+\mathrm{Rb}$ group showed no significant difference from the $\mathrm{C}$ group. However, SOD levels were significantly higher $(p<0.01)$ in the $\mathrm{Rb}+\mathrm{CNI}+\mathrm{Rb}$ group than in the CNI group (Figure 2b). The total NOS activity was significantly higher $(p<0.001)$ in the $\mathrm{CNI}$ group than in the $C$ group, while NOS activity in the treatment groups was comparable to that in the $\mathrm{C}$ group and significantly lower than in the CNI group (Figure 3a). cGMP and NGF levels were significantly lower $(p<0.001)$ in the CNI group when compared with the $\mathrm{C}$ group; moreover, the treatment groups had significantly higher levels $(p<0.001)$ than the $\mathrm{CNI}$ group (Figure $3 b$, 4). Another important finding was that the $\mathrm{Rb}+\mathrm{CNI}+\mathrm{Rb}$ group demonstrated significantly higher NGF levels than the $\mathrm{CNI}+\mathrm{Rb}$ group $(\mathrm{p}<0.05)$.

In the Western blot analysis for iNOS and nNOS, the $\mathrm{Rb}+\mathrm{CNI}+\mathrm{Rb}$ group demonstrated results similar to that in the $\mathrm{C}$ group, while the CNI group had significantly higher levels of iNOS and lower levels of nNOS (Figure 5).

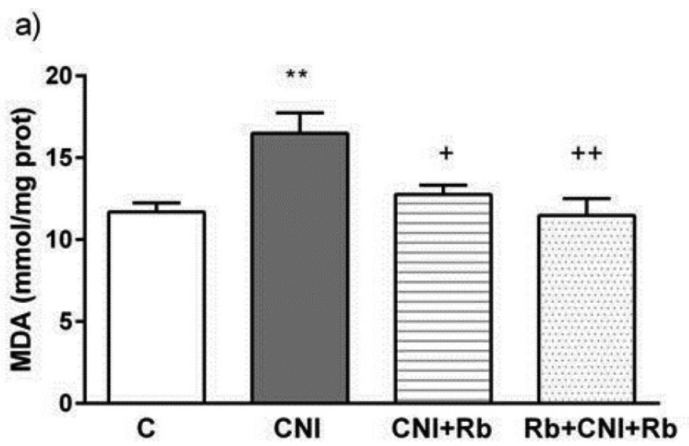

b)

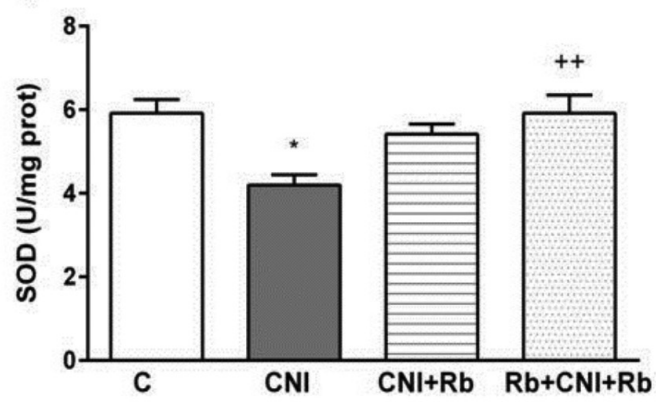

Figure 2. Cavernosal tissue analysis of; a) Malondialdehyde levels, b) Superoxide dismutase activity

C: Control, CNI: Cavernosal nerve injury, Rb: Riboflavin. ${ }^{*} p<0.05,{ }^{*} p<0.01$ : compared to group $C,+p<0.05,++p<0.01$ : compared to group $C N I$ 
Histological analysis of cavernosal tissues revealed that the C group demonstrated good alignment of smooth muscle bundles and the endothelium (Figure 6a), whereas in the CNI group, endothelial deterioration was prominent in addition to mild accumulation of leukocytes (Figure 6b). In the $\mathrm{CNI}+\mathrm{Rb}$ group, the endothelium showed moderate regression of degeneration (Figure $6 \mathrm{c}$ ), whereas the $\mathrm{Rb}+\mathrm{CNI}+\mathrm{Rb}$ group demonstrated good regeneration of the endothelium (Figure $6 d)$.
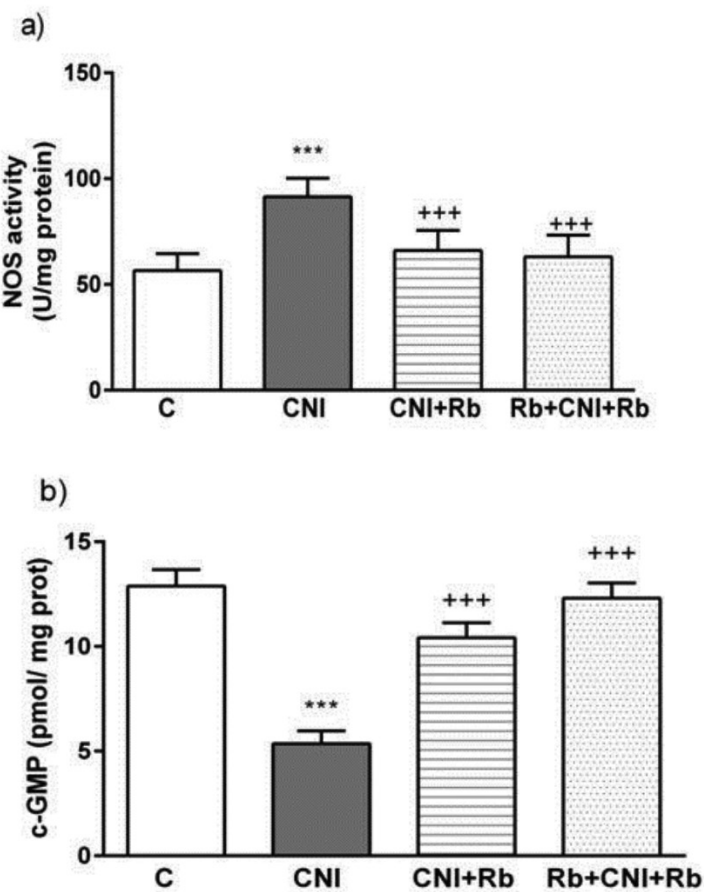

Figure 3. Cavernosal tissue analysis of; a) Nitric oxide synthase activity and, b) c-GMP levels

C: Control, CNI: Cavernosal nerve injury, Rb: Riboflavin, cGMP: cyclic guanosine monophosphate, ${ }^{* * *} p<0.001$ : compared to group $C_{t}{ }^{++} p<0.001$ : compared to group $\mathrm{CNI}$

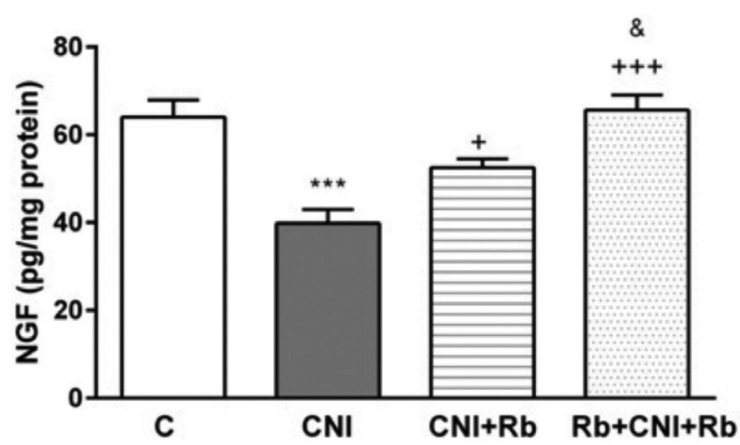

Figure 4. Nerve growth factor levels in cavernosal tissue

C: Control, CNI: Cavernosal nerve injury, Rb: Riboflavin, NGF: Nerve growth factor, ${ }^{* * *} p<0.001$ : compared to group $C_{1}{ }^{+} p<0.05,{ }^{++} p<0.001$ : compared to group $C N l_{1}$ Etp<0.05: compared to group $\mathrm{CNI}+\mathrm{Rb}$

\section{Discussion}

The current study indicates that $\mathrm{CNI}$ leads to inflammatory and oxidative damage in erectile tissue, with increased MDA levels in the cavernous tissue and decreased SOD activity. The elevated oxidative injury results in a reduction of the tissue anti-oxidant enzymes (7). In addition, while cGMP levels decreased, NOS activity increased, and both parameters are important for EF. Furthermore, the findings of the study clearly demonstrate that $\mathrm{Rb}$ reverses these changes to the $\mathrm{C}$ level and protects cavernous tissues against $\mathrm{CNI}$-mediated tissue damage.

We also determined NOS activities and cGMP levels, which are the main components of the NO/cGMP signaling pathway in

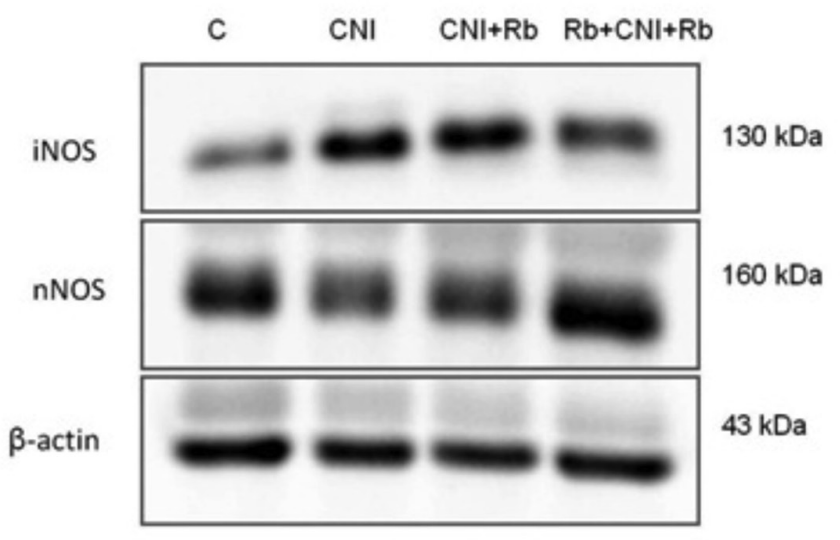

a)

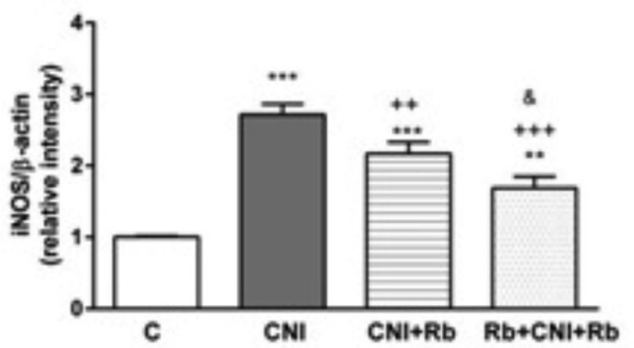

b)

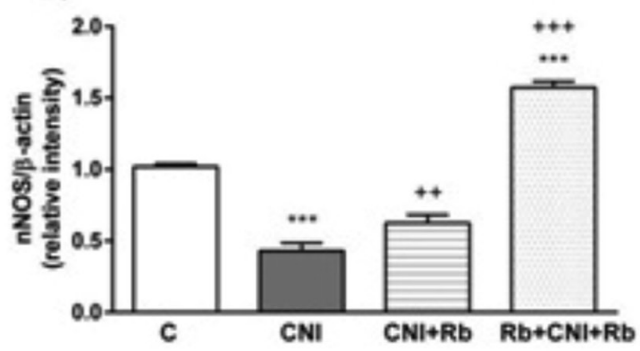

Figure 5. Western blot analysis in cavernosal tissue, a) inducible nitric oxide synthase ve b) neuronal nitric oxide synthase protein expressions

C: Control, CNI: Cavernosal nerve injury, Rb: Riboflavin, nNOS: Neuronal nitric oxide synthase, iNOS: inducible nitric oxide synthase, ${ }^{* *} p<0.01,{ }^{* * *} p<0.001$ : compared to group $C,{ }^{++} p<0.01,{ }^{+++} p<0.001$ : compared to group $C N I$, $\&$ $p<0.05$ : compared to $C N I+R b$ group 
the cavernous tissue. We observed increased total NOS activity in CNI rats (Figure 3a). As shown by Western blot analysis, the drop in nNOS expression was associated with nerve fiber injury, compatible with previous studies (Figure 5) $(16,19,31,32)$. Besides an elevation in iNOS expression, NGF levels also decreased, indicating that there was an apoptotic process in the $\mathrm{CN}$ fibers (Figure 4, 5) (12). With regard to a previous study, the increase in iNOS expression was normalized nearly to the $\mathrm{C}$ group by $\mathrm{Rb}$, which was prominent in the $\mathrm{Rb}+\mathrm{CNI}+\mathrm{Rb}$ group (6). There was also a significant difference in iNOS expression between the $\mathrm{Rb}+\mathrm{CNI}+\mathrm{Rb}$ and $\mathrm{CNI}+\mathrm{Rb}$ groups (Figure $5 \mathrm{a} ; \mathrm{p}<0.05$ ). The increase in total NOS activity could be related to the elevated iNOS expression in the CNI group.

NGF, which is the first discovered neurotrophic factor and signaling molecule, has important neuroprotective effects against several diseases $(12,33)$. We showed that NGF levels

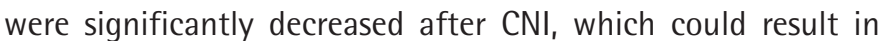
the development of ED. The current study showed that the Rbtreated pre-injury group $(\mathrm{Rb}+\mathrm{CNI}+\mathrm{Rb})$ had significantly higher NGF levels than the $\mathrm{CNI}$ and $\mathrm{CNI}+\mathrm{Rb}$ groups.

Similar to previous studies, the ICP/MAP values in $\mathrm{CNI}$ rats significantly decreased in our study $(7,31)$. Furthermore, the $\mathrm{Rb}$-treated groups had higher ICP/MAP values than the $\mathrm{CNI}$ group. The $\mathrm{Rb}+\mathrm{CNI}+\mathrm{Rb}$ group showed statistically significant differences from the CNI group and had values comparable to the $\mathrm{C}$ group (Figure 1). These data support the use of $\mathrm{Rb}$ for

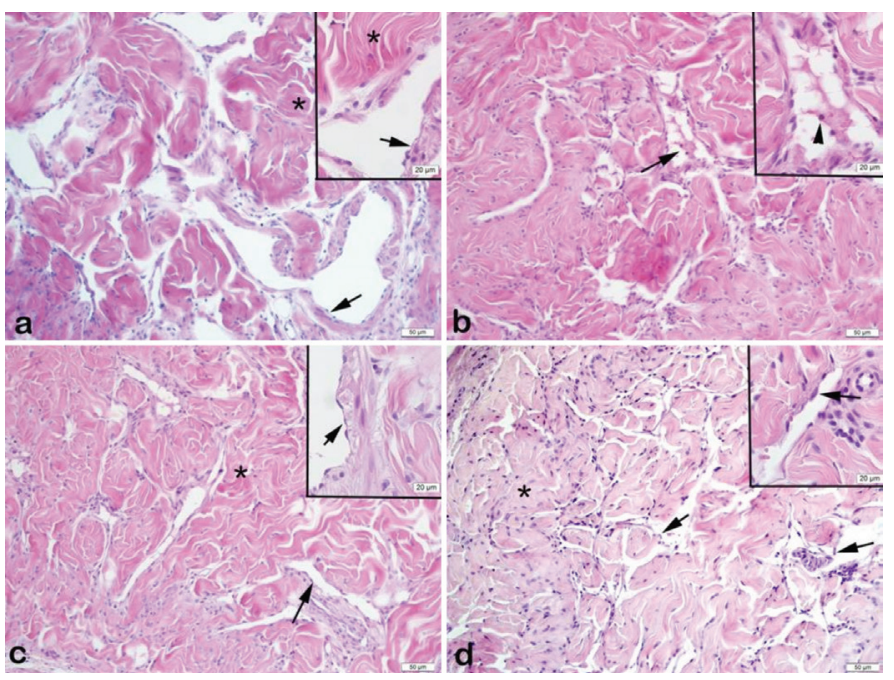

Figure 6. Histological analysis of cavernosal tissues, a) C group; smooth muscle bundles $\left({ }^{*}\right)$ surrounding vascular spaces, regular endothelial alignment (arrow). b) Cavernous nerve injury group; the prominent deterioration of vascular spaces and endothelium (arrow), sparsely observed leukocyte (arrowhead). c) Cavernous nerve injury + riboflavin group; the vascular endothelial cells have foamy cytoplasm (arrowhead) but vascular spaces were cleared away from deterioration (arrow), regular muscle bundles $\left(^{*}\right)$. d) Riboflavin + cavernous nerve injury + riboflavin group, clearly observed vascular spaces with regular endothelium cells (arrows), well-organized smooth muscle bundles (*) penile rehabilitation before $\mathrm{CNI}$, as proven through biochemical analysis.

Nevertheless, all penile rehabilitation strategies with PDE5i suggest the use of these agents after RP, following daily or on-demand protocols (34). No reported data was found except our previous study on the pre-injury treatment and pre-emptive penile rehabilitation, which is the first reported study on the data of pre-emptive penile rehabilitation before bilateral $\mathrm{CNI}$ in rats (35). According to these study results, pre-emptive penile rehabilitation with sildenafil (low- and high-dose) before bilateral CNI did not show a significant change in EF outcomes. Thus, our present study is the first one to demonstrate significant differences due to preemptive penile rehabilitation with $\mathrm{Rb}$ in $\mathrm{CNI}$ rats. Moreover, this is the first study in which $\mathrm{Rb}$ has been used for penile rehabilitation in a $\mathrm{CNI}$ rat model. The results of the current study show that $\mathrm{Rb}$ has protective effects on cavernous tissue after CNI.

\section{Study Limitations}

We only evaluated the effects of Rb in a CNI model; one arm of the study might be ordered with PDE5i and alone.

\section{Conclusion}

According to the results of this study, pathogenic CNI-induced ED causes oxidative stress to the cavernous tissue, and $\mathrm{Rb}$ can prevent injury to the erectile tissue. Furthermore, the results of this study suggest that preemptive use of $\mathrm{Rb}$ has a positive effect on oxidative parameters and improves all parameters towards the control levels. $\mathrm{Rb}$ can be considered a potential preventive agent in subjects undergoing RP, if supported with further studies, alone or with PDE5i.

\section{Ethics}

Ethics Committee Approval: Marmara University Animal Experiments Ethical Committee approved the study (number 78.2015.mar).

Informed Consent: None (Animal experiment).

Peer-review: Externally and internally peer-reviewed.

\section{Authorship Contributions}

Surgical and Medical Practices: M.E., H.H.T., T.E.Ş., G.Ş., Concept: M.E., H.H.T., T.E.Ş., G.Ş., Design: M.E., H.H.T., T.E.Ş., G.Ş., Data Collection or Processing: Ö.Ç., N.B., Ö.A., Ş.Ç., G.Ş., Analysis or Interpretation: Ö.Ç., N.B., Ö.A., Ş.Ç., G.Ş., Literature Search: H.H.T., T.E.Ş., M.E., Writing: H.H.T., T.E.Ş., G.Ş.

Conflict of Interest: No conflict of interest was declared by the authors. 
Financial Disclosure: The authors declared that this study received no financial support.

\section{References}

1. Ferlay J, Soerjomataram I, Dikshit R, Eser S, Mathers C, Rebelo M, Parkin DM, Forman D, Bray F. Cancer incidence and mortality worldwide: sources, methods and major patterns in GLOBOCAN 2012. Int J Cancer 2015;136:359386.

2. Cai LY, Kato T, Ito K, Nakayama M, Susa T, Aikawa S, Maeda K, Tsukamura H, Ohta A, Izumi S, Kato Y. Expression of porcine FSHbeta subunit promoterdriven herpes simplex virus thymidine kinase gene in transgenic rats. J Reprod Dev 2007;53:201-209.

3. Podlasek CA, Gonzalez CM, Zelner DJ, Jiang HB, McKenna KE, McVary KT. Analysis of NOS isoform changes in a post radical prostatectomy model of erectile dysfunction. Int J Impot Res 2001;13(Suppl 5):1-15.

4. Salonia $A$, Burnett $A L$, Graefen $M$, Hatzimouratidis $K$, Montorsi $F$, Mulhall $J$, Stief C. Prevention and management of postprostatectomy sexual dysfunctions. Part 1: choosing the right patient at the right time for the right surgery. Eur Urol 2012;62:261-272.

5. Agarwal A, Nandipati KC, Sharma RK, Zippe CD, Raina R. Role of oxidative stress in the pathophysiological mechanism of erectile dysfunction. J Androl 2006;27:335-347.

6. Ferrini MG, Davila HH, Kovanecz I, Sanchez SP, Gonzalez-Cadavid NF, Rajfer J. Vardenafil prevents fibrosis and loss of corporal smooth muscle that occurs after bilateral cavernosal nerve resection in the rat. Urology 2006;68:429-435

7. Lagoda G, Jin L, Lehrfeld TJ, Liu T, Burnett AL. FK506 and sildenafil promote erectile function recovery after cavernous nerve injury through antioxidative mechanisms. J Sex Med 2007;4:908-916.

8. User HM, Hairston JH, Zelner DJ, McKenna KE, McVary KT. Penile weight and cell subtype specific changes in a post-radical prostatectomy model of erectile dysfunction. J Urol 2003;169:1175-1179.

9. Beckman JS, Koppenol WH. Nitric oxide, superoxide, and peroxynitrite: the good, the bad, and ugly. Am J Physiol 1996;271:1424-1437.

10. Walsh PC. The discovery of the cavernous nerves and development of nerve sparing radical retropubic prostatectomy. J Urol 2007;177:1632-1635.

11. Burnett AL. Strategies to promote recovery of cavernous nerve function after radical prostatectomy. World J Urol 2003;20:337-342.

12. Miyamoto $K$, Inoue $S$, Kobayashi $K$, Kajiwara $M$, Teishima J, Matsubara A. Rat cavernous nerve reconstruction with $\mathrm{CD} 133+$ cells derived from human bone marrow. J Sex Med 2014;11:1148-1158.

13. Sezen SF, Hoke A, Burnett AL, Snyder SH. Immunophilin ligand FK506 is neuroprotective for penile innervation. Nat Med 2001;7:1073-1074.

14. Burnett $A L$, Allaf ME, Bivalacqua TJ. Erythropoietin promotes erection recovery after nerve-sparing radical retropubic prostatectomy: a retrospective analysis. J Sex Med 2008;5:2392-2398.

15. Jung GW, Kwak JY, Yoon S, Yoon JH, Lue TF. IGF-I and TGF-beta2 have a key role on regeneration of nitric oxide synthase (NOS)-containing nerves after cavernous neurotomy in rats. Int J Impot Res 1999;11:247-259.

16. Sezen SF, Blackshaw S, Steiner JP, Burnett AL. FK506 binding protein 12 is expressed in rat penile innervation and upregulated after cavernous nerve injury. Int J Impot Res 2002;14:506-512.

17. Kato R, Wolfe D, Coyle CH, Huang S, Wechuck JB, Goins WF, Krisky DM, Tsukamoto T, Nelson JB, Glorioso JC, Chancellor MB, Yoshimura N. Herpes simplex virus vector-mediated delivery of glial cell line-derived neurotrophic factor rescues erectile dysfunction following cavernous nerve injury. Gene Ther 2007;14:1344-1352.
18. Kim Y, de Miguel F, Usiene I, Kwon D, Yoshimura N, Huard J, Chancellor MB. Injection of skeletal muscle-derived cells into the penis improves erectile function. Int J Impot Res 2006;18:329-334.

19. Bochinski D, Lin GT, Nunes L, Carrion R, Rahman N, Lin CS, Lue TF. The effect of neural embryonic stem cell therapy in a rat model of cavernosal nerve injury. BJU Int 2004;94:904-909.

20. Lin G, Qiu X, Fandel $T$, Banie L, Wang G, Lue TF, Lin CS. Tracking intracavernously injected adipose-derived stem cells to bone marrow. Int J Impot Res 2011;23:268-275.

21. Chen KC, Minor TX, Rahman NU, Ho HC, Nunes L, Lue TF. The additive erectile recovery effect of brain-derived neurotrophic factor combined with vascular endothelial growth factor in a rat model of neurogenic impotence. BJU Int 2005;95:1077-1080.

22. Bochinski D, Hsieh PS, Nunes L, Lin GT, Lin CS, Spencer EM, Lue TF. Effect of insulin-like growth factor-1 and insulin-like growth factor binding protein-3 complex in cavernous nerve cryoablation. Int J Impot Res 2004;16:418-423.

23. Marashly ET, Bohlega SA. Riboflavin has neuroprotective potential: focus on Parkinson's disease and migraine. Front Neurol 2017;8:333.

24. Sakarcan $S$, Erşahin $M$, Eminoğlu $M E$, Çevik Ö, Ak E, Ercan $F$, Şener $G$. Riboflavin treatment reduces apoptosis and oxidative DNA damage in a rat spinal cord injury model. Clin Exp Healh Sci 2017;7:55-63.

25. Bertollo CM, Oliveira AC, Rocha LT, Costa KA, Nascimento EB Jr, Coelho MM. Characterization of the antinociceptive and anti-inflammatory activities of riboflavin in different experimental models. Eur J Pharmacol 2006;547:184191.

26. Mullerad M, Donohue JF, Li PS, Scardino PT, Mulhall JP. Functional sequelae of cavernous nerve injury in the rat: is there model dependency? J Sex Med 2006;3:77-83.

27. Mylroie AA, Collins H, Umbles C, Kyle J. Erythrocyte superoxide dismutase activity and other parameters of copper status in rats ingesting lead acetate. Toxicol Appl Pharmacol 1986;82:512-520.

28. Tavukcu HH, Sener TE, Tinay I, Akbal C, Ersahin M, Cevik O, Cadirci S, Reiter RJ, Sener G. Melatonin and tadalafil treatment improves erectile dysfunction after spinal cord injury in rats. Clin Exp Pharmacol Physiol 2014;41:309-316.

29. Bradford MM. A rapid and sensitive method for the quantitation of microgram quantities of protein utilizing the principle of protein-dye binding. Anal Biochem 1976;72:248-254.

30. Cevik O, Ersahin M, Sener TE, Tinay I, Tarcan T, Cetinel S, Sener A, Toklu HZ, Sener $G$. Beneficial effects of quercetin on rat urinary bladder after spinal cord injury. J Surg Res 2013;183:695-703.

31. Mulhall JP, Muller A, Donohue JF, Mullerad M, Kobylarz K, Paduch DA, Tal R, Li PS, Cohen-Gould L, Scardino PT. The functional and structural consequences of cavernous nerve injury are ameliorated by sildenafil citrate. J Sex Med 2008;5:1126-1136.

32. Hsieh PS, Bochinski DJ, Lin GT, Nunes L, Lin CS, Lue TF. The effect of vascular endothelial growth factor and brain-derived neurotrophic factor on cavernosal nerve regeneration in a nerve-crush rat model. BJU Int 2003:92:470-475.

33. Fiore $\mathrm{M}, \mathrm{Chaldakov} \mathrm{GN}$, Aloe L. Nerve growth factor as a signaling molecule for nerve cells and also for the neuroendocrine-immune systems. Rev Neurosci 2009;20:133-145.

34. Blecher G, Almekaty K, Kalejaiye 0, Minhas S. Does penile rehabilitation have a role in the treatment of erectile dysfunction following radical prostatectomy? F1000Res 2017;6:1923.

35. Tavukcu HH, Akbal C, Tinay I, Simsek F, Türkeri L. Outcome of preemptive penile rehabilitation before bilateral cavernosal nerve injury in rats. World $J$ Urol 2010;28:735-740. 